\title{
Ontogenetic allometry in the foot size of Oligoryzomys flavescens (Waterhouse, 1837) (Rodentia, Sigmodontinae)
}

\author{
Maestri, R..$^{a, b, *}$, Fornel, . $^{c}$, Freitas, TRO.$^{d}$ and Marinho, JR. ${ }^{c}$ \\ aPrograma de Pós-Graduação em Ecologia, Universidade Regional Integrada do Alto Uruguai e das Missões - URI, \\ Campus Erechim, Av. Sete de Setembro, 1621, CEP 99700-000, Erechim, RS, Brazil \\ bPrograma de Pós-Graduação em Ecologia, Universidade Federal do Rio Grande do Sul - UFRGS, \\ Av. Bento Gonçalves, 9500, CEP 91501-970, Porto Alegre, RS, Brazil

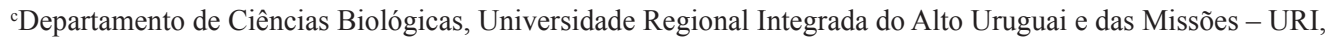 \\ Campus Erechim, Av. Sete de Setembro, 1621, CEP 99700-000, Erechim, RS, Brazil \\ dDepartamento de Genética, Universidade Federal do Rio Grande do Sul - UFRGS, \\ Av. Bento Gonçalves, 9500, CEP 91501-970, Porto Alegre, RS, Brazil \\ *e-mail: renanmaestri@gmail.com
}

Received: September 13, 2013 - Accepted: December 4, 2013 - Distributed: May 31, 2015

(With 3 figures)

\begin{abstract}
Ontogenetic allometry is the study of how the size or shape of certain structures changes over the course of an animal's development. In this study, using Huxley's formula of allometric growth (1932), we assessed the changes in the rate of growth of the feet size of the sigmodontine rodent Oligoryzomys flavescens during its ontogeny and compared differences between males and females. We find evidence of a change of polarity during the ontogenetic development of the species, with the presence of positive allometry during pregnancy and negative allometry in adulthood. Moreover, we note the presence of sexual dimorphism in the size of the feet, in which males of the species have a higher rate of growth than females. This growth pattern is positively related to escape from predators in childhood in both sexes and, in adulthood, provides a higher encounter rate of females by males, due to the larger displacement of the latter. We suggest that both the forces of natural selection and sexual selection have acted to shape the evolution of foot size in this species.
\end{abstract}

Keywords: linear measures, ontogenetic trajectory, bipedal locomotion, sexual dimorphism.

\section{Alometria ontogenética no tamanho dos pés em Oligoryzomys flavescens (Waterhouse, 1837) (Rodentia, Sigmodontinae)}

\section{Resumo}

A alometria ontogenética estuda como o tamanho ou forma de determinada estrutura muda ao longo do desenvolvimento. Neste estudo, através da fórmula do crescimento alométrico de Huxley (1932), acessamos as variações na taxa de crescimento do tamanho dos pés do roedor sigmodontineo Oligoryzomys flavescens, ao longo de sua ontogenia e entre machos e fêmeas. Nós encontramos evidência de uma mudança de polaridade ontogenética ao longo do desenvolvimento da espécie, com presença de alometria positiva na fase gestacional, e alometria negativa na fase adulta. Além disso, constatamos a presença de dimorfismo sexual no tamanho dos pés, onde machos da espécie apresentam uma maior taxa de crescimento nesta característica em comparação com as fêmeas. Esse padrão de crescimento deve estar positivamente relacionado com a fuga de predadores na infância em ambos os sexos, e na vida adulta propicia uma maior taxa de encontro de fêmeas pelos machos, devido ao maior deslocamento destes últimos. Sugerimos que tanto as forças da seleção natural quanto da seleção sexual tem atuado para moldar a evolução do tamanho dos pés nesta espécie.

Palavras-chave: medidas lineares, trajetória ontogenética, locomoção bípede, dimorfismo sexual.

\section{Introduction}

Evolutionary changes in specific morphological characteristics require changes in developmental processes that produce that structure. Thus, changes in ontogenetic trajectory can affect the evolution of a taxonomic group in multiple ways along its evolutionary history (Klingenberg, 1998). Analysis of morphological changes in ancestral and descendant taxa and comparison between modern groups may indicate the presence of heterochrony (i.e., change 
in time or rate of events during development) and reveal whether the differences are the result of paedomorphosis or peramorphosis (Klingenberg, 1998).

Analyses of ontogeny restricted to a single species are not enough to explain the direction of evolutionary change in certain structures within taxonomic groups; these analyses also cannot define the growth of a structure as paedomorphic or peramorphic, leaving the realm of heterochrony. However, this allometric approach allows us to associate the change in size or shape of a given structure with the variation in the total size of the organism (Vassallo and Mora, 2007). Thus, changes in the growth of body parts throughout ontogeny can be measured.

One of the ways to measure ontogenetic trajectory for a feature of interest is through allometric growth curves, where measurements of two characteristics are plotted against each other (e.g., a structure of interest is plotted against body size at different stages of development). In this case, the time (i.e., age of the organism at different stages) is taken into account only indirectly through the relative growth rate (Klingenberg, 1998). Both the size and the shape of a given structure of interest can be plotted against the overall body size to obtain the relative growth rate of the structure in relation to body size. Multivariate allometry, which includes the change in shape of the target structure relative to body size, has been widely studied, especially with the emergence and popularity of geometric morphometric techniques (Breno et al., 2011; Cardini and Thorington Junior, 2006; Webster and Zelditch, 2005; Zelditch et al., 2000). However, variations in the size of a morphological trait have been studied more than variations in shape, mainly because it is easier to quantify changes in size than shape (Renaud and Michaux, 2003).

Allometry studies with Neotropical rodents are uncommon, and a small number of studies have used allometry to investigate sigmodontine traits (Bozinovic and Rosenmann, 1988; López-Fuster et al., 2001; Lovegrove, 2010; Martínez and Di Cola, 2011). The species Oligoryzomys flavescens (subfamily Sigmodontinae, tribe Oryzomyini) is distributed throughout much of the Brazilian Atlantic Forest, and it can also be found in southern Brazil and parts of Argentina, Paraguay and Uruguay, occupying forest, grassland and anthropogenic habitats (Reis et al., 2006; Miranda et al., 2009). It is a small species, with the body length of adults ranging between approximately 81 and $93 \mathrm{~mm}$, with a color ranging from brown to light brown and thin, long legs with clear foot and interdigital pads (Bonvicino et al., 2008; Machado et al., 2011). Initial field observations indicated that the feet of the juveniles of this species are large in comparison to the rest of the body, which is the origin of this research.

In this study, we turn our attention to the changes in the foot size of the species Oligoryzomys flavescens throughout its ontogeny. We also infer possible causes for ontogenetic changes in morphology, with a view to the evolution of the group. Specifically, our goal was to test three hypotheses: (a) there is an allometric relationship in the foot growth of Oligoryzomys flavescens; (b) there is sexual dimorphism in the foot size; and as a result, (c) there is a difference in the growth rates between the feet of males and females.

\section{Material and Methods}

We collected 343 specimens of $O$. flavescens in a single field study between August 2011 and September 2012, resulting in the collection of 194 juveniles and 149 adults. Data collection was conducted in a section of seasonal deciduous forest in the Atlantic Forest domain, located in the city of Chapecó, Santa Catarina state, southern Brazil. Pitfall traps were used to capture the rodents. Ten plastic containers were installed with a capacity of 100 liters in five sampling points and were sampled monthly for ten consecutive days during the field period. The organisms were collected with consent from the relevant environmental agencies, under permanent license No.15224-2 (ICMBIO). Euthanasia was performed taking into account the welfare of the animal through sedation with inhaled anesthetic, which produces rapid unconsciousness and subsequent death without evidence of pain or agony, as required by resolution of the Federal Board of Biology of Brazil (article 8, resolution number 301, December 8, 2012). The specimens were deposited in the Museu Regional do Alto Uruguai - Universidade Regional Integrada do Alto Uruguai e das Missões, Campus Erechim, Rio Grande do Sul, Brazil. The serial numbers of specimens are listed in Appendix.

The body length without tail (CC) (measured from the tip of the snout to the end of the body, without tail) and length of the right foot with nail (CP) in millimeters $(0.05 \mathrm{~mm})$ was measured with a graduated ruler for all individuals collected. Three pregnant females at different stages of pregnancy, each with three embryos, were collected, and the same measurements were collected for the embryos. Only one embryo was left out of the analysis because its developmental stage did not allow the measurement of foot length.

To analyze the allometric growth of foot size in relation to body size, a simple linear regression was performed with the log-transformed $\mathrm{CP}(\mathrm{Y})$ and $\mathrm{CC}(\mathrm{X})$. Using the allometric growth formula $\left(\mathrm{Y}=\mathrm{aX} \mathrm{X}^{\mathrm{b}}\right)$ (Huxley, 1932) with the log-transformed data $(\ln Y=\operatorname{lna}+b \ln X)$, we can find the allometry coefficient (b) through simple regression (Müller et al., 2012; Klingenberg, 1998; Mandarim-de-Lacerda, 1995). If the allometric coefficient is equal to $1(b=1)$, the growth of $\mathrm{Y}$ in relation to $\mathrm{X}$ occurs isometrically; if $\mathrm{b}<1$, $Y$ has negative allometry, i.e., Y grows more slowly than $X$; if $\mathrm{b}>1$, $\mathrm{Y}$ has positive allometry, i.e., $\mathrm{Y}$ grows more quickly than X (Vassallo, 2000; Klingenberg, 1998). Tests were performed separately for two main groups of individuals: prenatal and postnatal individuals.

Similarly, we tested the difference in allometric growth between males and females of the species. In this case, only the adults that could be sexed were used. Adult individuals were identified as those with the third molar completely eroded. This sample included 78 males and 71 females. To assess the difference in the growth rate of the feet between males and females, we calculated a confidence interval for this difference. This interval was calculated by obtaining the difference between the allometry coefficient (b) of males and females and using this value as a statistic in a bootstrap test. The difference between the slopes (i.e., b) served as the difference in growth rates because it is a measure of the 
slope of the straight lines. Through bootstrapping (resampled 10,000 times) of Y-values (foot length) of males and females, we obtained an estimate of the probability of encountering the same growth rate. Similar to the methods of Sheets and Zelditch (2013), we tested the null hypothesis that the value of the observed difference ( $b$ male $-b$ female) was not greater than the difference that could be found by random selection of samples. We then obtained a percentage value that expressed the number of times that the random difference was less than or equal to the observed value relative to the number of tests, which served as a confidence index of the difference in growth rates of the foot.

With Student's t-test, we evaluated whether there was difference in the length of the body and foot length between males and females. In this case, the data were log-transformed to ensure homoscedasticity, and data normality was verified visually. All statistical tests were performed using R software (R Development Core Team, 2012) with the MASS library.

\section{Results}

The body length of the 343 postnatal individuals collected ranged from $39 \mathrm{~mm}$ to $95 \mathrm{~mm}$ (mean: 67.7; mode: 75; median: 70). The foot length ranged from $14 \mathrm{~mm}$ to $33 \mathrm{~mm}$ (mean: 23.2; mode: 24; median: 23.25). The CP-CC regression (CP: foot length; $\mathrm{CC}$ : body length) of postnatal individuals resulted in $b=0.31$, and the regression of the values from embryos resulted in $b=1.42$ (Figure 1). The statistical and graphical analyses indicated that the feet of prenatal individuals have faster growth relative to the body in comparison to postnatal individuals. However, there is a gap between the largest embryo and the smallest postnatal individual of the species. Therefore, the growth during pregnancy or even up to birth must have a positive allometric value. We suspect that there is an isometric growth phase between the end of pregnancy and the early stages of life, which likely continues for a short time after birth, then reaching and staying in negative allometric growth for the remainder of the development. To determine when this short period of isometric growth occurs in ontogenetic development, we examined different groups of postnatal individuals to determine when the change to linear isometric growth occurred $(b=1)$ (Figure 2$)$. The results indicate that the 20 smaller specimens displayed isometric growth. The last individual in this sample (i.e., the largest within the range of isometry) had a foot length of $20 \mathrm{~mm}$ and a body length of $46.3 \mathrm{~mm}$.

In the test for sexual dimorphism, we observed a significant difference in the foot length between males and females $\left(\mathrm{F}_{(1,147)}=16.54 ; \mathrm{p}<0.0001\right)$. The mean of the foot length was $24.53( \pm 1.12)$ for males and $23.72( \pm 1.24)$ for females. Body size did not differ significantly between males and females $\left(\mathrm{F}_{(1,147)}=2.35 ; \mathrm{p}=0.127\right)$. The mean of the body size was $72.62( \pm 7.76)$ for males and $71.58( \pm 6.95)$ for females. We also noticed a divergence in ontogenetic trajectories of males and females (Figure 3), where the vector for males visually presented a higher growth rate compared to females. The confidence interval of the difference in the growth rates, obtained through bootstrapping, was $87.42 \%$.

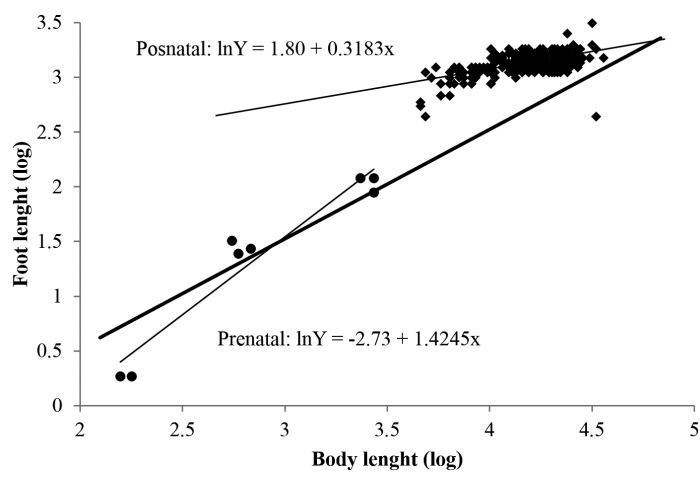

Figure 1. Regression between the length of the foot (log-mm) and the length of the body (log-mm) of individuals of Oligoryzomys flavescens collected in a fragment of seasonal deciduous forest in Chapecó, Santa Catarina, southern Brazil. The diamonds represent the 343 individuals born and the circles represent the eight embryos. The darker line represents the isometric growth $(b=1)$.

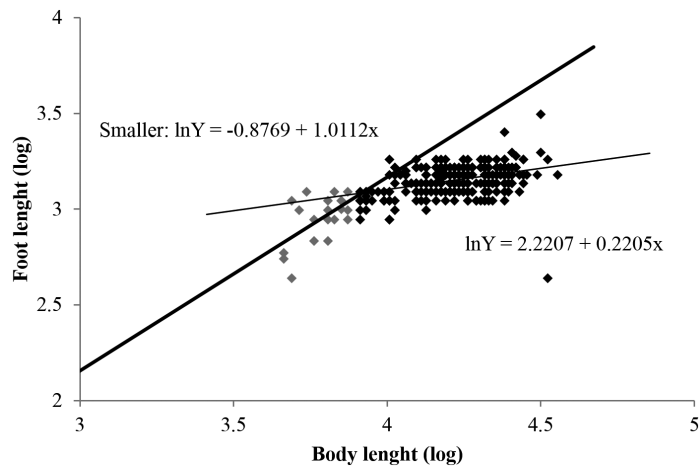

Figure 2. Regression between the body length (log-mm) and the length of the foot (log-mm) of individuals of Oligoryzomys flavescens collected in a fragment of seasonal deciduous forest in Chapecó, Santa Catarina, southern Brazil. The gray diamonds represent the 20 smaller individuals born of the species, and the dark diamonds represent the remaining 323 . The tracing that represents the smallest individuals overlaps with the darker line of isometric growth $(b=1)$.

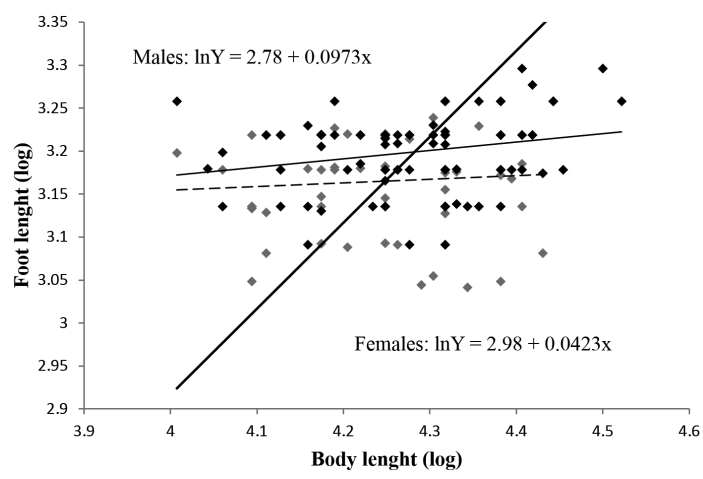

Figure 3. Scatter plot showing the differences in growth rates of foot size in relation to body size for males and females. The black diamonds and solid line represent males and gray diamonds and dashed line represent females. The darker line representing the isometric growth $(b=1)$. Only adults are represented. 


\section{Discussion}

Our results support two main findings - the change in polarity of the allometric growth (i.e., positive in one phase, negative in another) and the presence of differences in foot growth rate between males and females.

\subsection{Allometric growth}

We demonstrate that throughout the development of the species Oligoryzomys flavescens, from gestational stage until adulthood, individuals go through a prenatal stage of rapid foot growth, and following birth, the foot growth rate gradually decreases. Therefore, there is a change in the allometric polarity during ontogeny. There is a major investment in the growth of the feet at a certain stage and then more is invested in other parts of the body, making foot growth slower than the growth of the body as a whole.

Similar results were found by Wilson (2011) when studying the allometry of cranial elements in the rodent Rhabdomys pumilio. The growth rate of the bony structures in the prenatal phase was greater than in the postnatal phase, with a comparatively greater tendency for positive allometry during gestation and negative allometry or isometry in the postnatal phase. This general pattern agrees with the idea of rapid expansion of the brain and cranial elements in the prenatal phase (Wilson, 2011).

In sigmodontine rodents, general adaptive characteristics of the feet and the wide variation of shapes and sizes within the subfamily have been long noted. Hershkovitz (1972) compare the characteristics of the feet between species of Muridae and drew attention to the large feet of terrestrial rodents with scansorial habits, citing the genus Oligoryzomys as an example. However, to date, no study had addressed the growth of the feet of these rodents across a wide range of sizes covering the ontogenetic variation of this species. Based on our findings, we developed some potential explanations for the observed growth pattern.

The higher allocation of resources to foot growth during gestation suggests, at first glance, that there are selective reasons for this fact, i.e., there is some advantage for individuals born with large feet. Therefore, it can be assumed that there is some positive selection for this trait. From this initial proposition, we suggest a potential hypothesis to explain the selective advantage of have large feet at birth is differences in survival due to facilitated locomotion.

The mode of locomotion of the species of the genus Oligoryzomys can be considered terrestrial-climber (Rivas and Linares, 2006), with an affinity for locomotion by jumping and climbing (Bonvicino and Oliveira, 2006). Mares (1983) described the genus as having bipedal locomotion. These modes of mobility result in conditions where large feet would provide a selective advantage because pulse locomotion is facilitated by larger feet. One can clearly see these advantages by observing the marsupials of the family Macropodidae (kangaroos). The species of this family have large hind feet, whose main function is to provide support for its rapid locomotion by leaps (Hume et al., 1989). In addition to this remarkable case, we found similar cases within the order Rodentia. The rodents of the family Dipodidade (e.g., Dipodomys spp.) have disproportionately large feet as an adaptation to saltatorial locomotion (Wilson and Gardner, 1990). In this genus, as in other desert inhabitants of the family Heteromyidae, the presence of bipedalism has direct consequences on the speed of movement and leaping distance (Price, 1993). Oligoryzomys flavescens inhabits both forest regions and natural and anthropogenic open areas over a wide geographic distribution (Eisenberg and Redford, 1999; Bonvicino et al., 2008), which suggests a locomotive adaptation to diverse environments. Nevertheless, the emergence of bipedalism in species of small mammals is more common in open areas, such as deserts (Mares, 1993). In these regions, the risk of predation is one of the most important factors influencing the behavior of the species (Longland and Price, 1991; Kramer and Birney, 2001). In this way, the generalist habits of $O$. flavescens can combine more effectively with locomotion by leaps.

Nevertheless, because juveniles need more defenses against predators than adults, a rapid locomotion in early childhood may be essential in escaping from predators because the young, due to their fragility and inexperience, are easy targets for predators, such as owls, which capture this class of individuals more often (Bueno, 2005). Moreover, juvenile rodents can travel long distances in search of their own home range (Camelo-Neto et al., 2008), which increases their chances of detection by predators. In these cases, bipedal locomotion is considered more effective than quadrupedal in escaping from predators because it allows for greater speed, rapid response to attacks from predators, and sudden changes in direction (Taraborelli et al., 2003). It is, therefore, possible that the rapid onset of the feature has been selected for because it affects the survival of individuals starting at birth.

\subsection{Sexual dimorphism}

The difference in length of the feet between males and females suggests that the feature could be the result of sexual selection. The fact that the same difference is not observed in body size shows that the foot dimorphism is not a consequence of dimorphism in body size, but rather the selection object itself. One of the ways by which sexual selection operates is characterized by active choice of males by females. However, there is no information in the literature suggesting any type of sexual selection in Neotropical rodents. Nevertheless, it seems strange to argue that females of the species visually select males based on the length of the feet. It is more likely that there is some form of non-invasive competition, such as ecological selection, where males with larger feet have more access to females in general, perhaps because they are faster, which, as a result, increases their rate of encounter with females throughout life, resulting in more descendants.

We can say with a good degree of confidence $(87.42 \%)$ that the foot size dimorphism is the result of a difference in growth rate of feet during development. As shown in Figure 3, this difference increases over time in adult life, 
meaning that the proportional reduction in foot growth is less pronounced in males, resulting in their feet being bigger. As already mentioned, we assume that large feet are positively selected for in childhood for both sexes, which in turn explains the small size difference in the feet of males and females in young individuals. This constraint imposed in childhood by natural selection maintains the similar foot size up to a certain stage of life, perhaps at the reproductive period, where the differences start to become more pronounced due to sexual selection. In other words, there is a positive allometry that affects all individuals in the early stages of life, and, at some point (which we posit to be the reproductive period), there is an inversion in polarity, which causes a period of negative allometric growth but with different rates for males and females.

Thus, we can conclude that foot size is most likely selected for in all individuals (regardless of sex) at birth because it affects survival. Later, in adulthood, the selection pressure for survival is reduced, and feet reach an optimal size for survival. However, in the reproductive phase, males with larger feet have greater access to females. This advantage may have caused, over the generations, an increase in the foot growth rate in males. This growth in males is more than is necessary for survival, but it can ensure a higher rate of encounter with females. In this way, we suggest that both natural selection and sexual selection are guiding the evolution of foot size in this species.

Finally, it is necessary note some limitations of our study. All our assumptions were made based on natural selection, assuming that these features are adaptive. However, natural selection may not be the explanation specifically for $O$. flavescens. This feature might occur in this species simply as effect of its phylogenetic history. For example, if the trait emerged in a remote ancestor as an effect of selective pressure or otherwise (i.e., genetic drift), it may have simply remained in the species without a current pressure to maintain the characteristic. Testing this same growth relationship in other rodent species, closely and distantly related, may help to clarify the origin of the feature. In addition, comparisons between species with distinct locomotion modes could elucidate some of the reasons for the presence of the characteristic in this species. Despite these limitations, the information presented in this study is novel for Neotropical rodents, for which there are still few morphological and dimorphic studies. In addition, this is the first reported case of sexual dimorphism in foot length for Neotropical rodents.

\section{Acknowledgements}

We are grateful to the CAPES for granting a scholarship to the first author.

\section{References}

BONVICINO, CR. and OLIVEIRA, JA., 2006. Ordem Rodentia. In REIS, NR., PERACCHI, AL., PEDRO, WA. and LIMA, IP. (Eds.). Mamiferos do Brasil. Londrina: Edifurb. p. 347-399.
BONVICINO, CR., OLIVEIRA, JA. and D'ANDREA, PS., 2008. Guia dos roedores do Brasil, com chave para gêneros baseadas em caracteres externos. Rio de Janeiro: Centro Panamericano de Febre Aftosa/ OPAS/ OMS. 120 p.

BOZINOVIC, F. and ROSENMANN, M., 1988. Comparative energetics of South American cricetid rodents. Comparative Biochemistry and Physiology. A. Comparative Physiology, vol. 91, no. 1, p. 195-202. http://dx.doi.org/10.1016/0300-9629(88)916167. PMid:2904330

BRENO, M., LEIRS, H. and VAN DONGEN, S., 2011. Traditional and geometric morphometrics for studying skull morphology during growth in Mastomys natalensis (Rodentia: Muridae). Journal of Mammalogy, vol. 92, no. 6, p. 1395-1406. http:// dx.doi.org/10.1644/10-MAMM-A-331.1.

BUENO, AA., 2005. Vulnerabilidade de pequenos mamíferos de áreas abertas a vertebrados predadores na Estação Ecológica de Itirapina, SP. Biota Neotropica, vol. 5, no. 2, p. 1-2.

CAMELO-NETO, G., SILVA, ATC., GIUGGIOLI, L. and KENKRE, VM., 2008. Effect of predators of juvenile rodents on the spread of the hantavirus epidemic. Bulletin of Mathematical Biology, vol. 70, no. 1, p. 179-188. http://dx.doi.org/10.1007/ s11538-007-9247-4. PMid:17694347

CARDINI, A. and THORINGTON JUNIOR, RW., 2006. Postnatal ontogeny of marmot (Rodentia, Sciuridae) crania: allometric trajectories and species divergence. Journal of Mammalogy, vol. 87, no. 2, p. 201-215. http://dx.doi.org/10.1644/05-MAMM-A242R1.1.

EISENBERG, JF. and REDFORD, KH., 1999. The Central Neotropics: Ecuador, Peru, Bolivia, Brasil. 1st ed. Chicago: The University of Chicago Press. 609 p. Mammals of the Neotropics, no. 3 .

HERSHKOVITZ, P., 1972. The recent mammals of the Neotropical region: a zoographic and ecological review. In KEAST, A., ERK, FC. and GLASS, B. (Eds.). Evolution, mammals, and southern continents. New York: State University of New York Press. p. 311-432.

HUME, ID., JARMAN, PJ., RENFREE, MB. and TEMPLESMITH, PD., 1989. Macropodidae. In WALTON, DW. and RICHARDSON, BJ. (Eds.). Fauna of Australia. Canberra: AGPS Canberra. p. 915-985. Fauna of Australia, no. 1B.

HUXLEY, J., 1932. Problems of relative growth. London: MacVeagh. 277 p.

KLINGENBERG, CP., 1998. Heterochrony and allometry: the analysis of evolutionary change in ontogeny. Biological Reviews of the Cambridge Philosophical Society, vol. 73, no. 1, p. 79-123. http://dx.doi.org/10.1017/S000632319800512X. PMid:9569772

KRAMER, KM. and BIRNEY, EC., 2001. Effect of light intensity on activity patterns of Patagonian leaf-eared mice, Phyllotis xanthopygus. Journal of Mammalogy, vol. 82, no. 2, p. 535-544. http://dx.doi.org/10.1093/jmammal/82.2.535.

LONGLAND, WS. and PRICE, MV., 1991. Direct observations of owls and heteromyid rodents: can predation risk explain microhabitat use? Ecology, vol. 72, no. 6, p. 2261-2273. http:// dx.doi.org/10.2307/1941576.

LÓPEZ-FUSTER, MJ., PÉREZ-HERNÁNDEZ, R. and VENTURA, J., 2001. Variación craneométrica de Rhipidomys latimanus venezuelae (Muridae, Sigmodontinae). Orsis, vol. 16, p. 111-120. 
LOVEGROVE, BG., 2010. The allometry of rodent intestines. Journal of Comparative Physiology. B, Biochemical, Systemic, and Environmental Physiology, vol. 180, no. 5, p. 741-755. http://dx.doi.org/10.1007/s00360-009-0437-2. PMid:20063002

MACHADO, LF., PARESQUE, R. and CHRISTOFF, AU., 2011. Anatomia comparada e morfometria de Oligoryzomys nigripes e O. flavescens (Rodentia, Sigmodontinae) no Rio Grande do Sul, Brasil. Papéis Avulsos de Zoologia, vol. 51, no. 3, p. 29-47.

MANDARIM-DE-LACERDA, CA., 1995. Métodos quantitativos em morfologia. Rio de Janeiro: UERJ. $131 \mathrm{p}$.

MARES, MA., 1983. Desert rodent adaptation and community structure. In REICHMAN, OJ. and BROWN, JH. (Eds.). Biology of desert rodents. Utah: Brigham Young University. p. 30-73.

MARES, MA., 1993. Desert rodents, seed consumption, and convergence. Evolutionary shuffling of adaptations. Bioscience, vol. 43, no. 6, p. 372-379. http://dx.doi.org/10.2307/1312045.

MARTÍNEZ, JJ. and DI COLA, V., 2011. Geographic distribution and phenetic skull variation in two close species of Graomys (Rodentia, Cricetidae, Sigmodontinae). Zoologischer Anzeiger, vol. 250, no. 3, p. 175-194. http://dx.doi.org/10.1016/j.jcz.2011.03.001.

MIRANDA, JMD., MORO-RIOS, RF., SILVA-PEREIRA, JE. and PASSOS, FC., 2009. Guia ilustrado mamíferos da Serra de São Luiz do Purunã, Paraná, Brasil. Pelotas: USEB. 200 p.

MÜLlER, DWH., CODRON, D., WERNER, J., FRITZ, J., HUMMEL, J., GRIEBELER, EM. and CLAUSS, M., 2012. Dichotomy of eutherian reproduction and metabolism. Oikos, vol. 121 , no. 1 , p. 102-115. http://dx.doi.org/10.1111/j.16000706.2011.19505.x.

PRICE, MV., 1993. A functional-morphometric analysis of forelimbs in bipedal and quadrupedal heteromyid rodents. Biological Journal of the Linnean Society. Linnean Society of London, vol. 50, no. 4, p. 339-360. http://dx.doi.org/10.1111/j.1095-8312.1993.tb00936.x.

R Development Core Team, 2012. R: A language and environment for statistical computing. R Foundation for Statistical Computing. Available from: <http://www.R-project.org/>. Access in: 14 Aug. 2013.

REIS, NR., PERACCHI, AL., PEDRO, WA. and LIMA, IP., 2006. (Eds.). Mamíferos do Brasil. Londrina: Edifurb. 437 p.
RENAUD, S. and MICHAUX, JR., 2003. Adaptative latitudinal trends in the mandible shape of Apodemus wood mice. Journal of Biogeography, vol. 30, no. 10, p. 1617-1628. http://dx.doi. org/10.1046/j.1365-2699.2003.00932.x.

RIVAS, BA. and LINARES, OJ., 2006. Cambios en La forma de La pata posterior entre roedores sigmodontinos según su locomoción y hábitat. Mastozoología Neotropical, vol. 13, no. 2, p. 205-215.

SHEETS, HD. and ZELDITCH, ML., 2013. Studying ontogenetic trajectories using resampling methods and landmark data. Hystrix, the Italian Journal of Mammalogy, vol. 24, no. 1, p. 67-73.

TARABORELLI, P., CORBALÁN, V. and GIANNONI, S., 2003. Locomotion and scape modes in rodents of the monte desert (Argentina). Ethology, vol. 109, no. 6, p. 475-485. http://dx.doi. org/10.1046/j.1439-0310.2003.00884.x.

VASSALLO, AI. and MORA, MS., 2007. Interespecific scaling and ontogenetic growth patterns of the skull in living and fossil Ctenomyid and Octodontid rodents (Caviomorpha: Octodontoidea). University of California Publications in Zoology, p. 945-968.

VASSALLO, AI., 2000. Alometría e Isometría en varias especies de roedores caviomorfos, com comentários sobre la estructura del aparato masticatorio del orden Rodentia. Mastozoología Neotropical, vol. 7, no. 1, p. 37-46

WEBSTER, M. and ZELDITCH, ML., 2005. Evolutionary modifications of ontogeny: heterochrony and beyond. Paleobiology, vol. 31, no. 3, p. 354-372. http://dx.doi.org/10.1666/00948373(2005)031[0354:EMOOHA]2.0.CO;2.

WILSON, DE. and GARDNER, AL., 1990. Mammalian species. The American Society of Mammalogists, vol. 353, p. 1-10.

WILSON, LAB., 2011. Comparison of prenatal and postnatal ontogeny: cranial allometry in the African striped mouse (Rhabdomys pumilio). Journal of Mammalogy, vol. 92, no. 2, p. 407-420. http://dx.doi.org/10.1644/10-MAMM-A-209.1.

ZELDITCH, ML., SHEETS, HD. and FINK, WL., 2000. Spatiotemporal reorganization of growth rates in the evolution of ontogeny. Evolution; International Journal of Organic Evolution, vol. 54, no. 4, p. 1363-1371. http://dx.doi.org/10.1111/j.0014-3820.2000. tb00568.x. PMid:11005302 


\section{Appendix}

List of individuals used in the study. Numbers refers to the location in the "Museu Regional do Alto Uruguai" - MURAU. Oligoryzomys flavescens:

$305-307 ; 312 ; 322 ; 326 ; 348 ; 349 ; 363$ - 367; 372; 382; 383; 407; 413; 430 - 439; 442 - 445; 448; 454; 462 - 469; 480 ; $498-516 ; 522-542 ; 546-548 ; 558 ; 567-578 ; 584-594 ; 596 ; 598 ; 599 ; 601 ; 604-613 ; 615 ; 617-623$; $626 ; 629 ; 635-638 ; 646-649 ; 653-658 ; 662 ; 670-677 ; 679-681 ; 688 ; 693-696 ; 705 ; 718-731 ; 734-738$; 741 - 744; 751 - 760; $769-782 ; 791-799 ; 804-808 ; 812-815 ; 819-857 ; 861-874 ; 880-885 ; 897$ - 963 ; $968-1020 ; 1027 ; 1029 ; 1033-1057 ; 1061$. 